\title{
Association of Eyelid Disorders and Ocular Motility Disorders in Pediatric Age: an Epidemiologic Analysis. A Multicenter Retrospective Study.
}

\section{Matteo Ripa}

Ophthalmology Unit, "Fondazione Policlinico Universitario A. Gemelli IRCCS”, Rome, Italy

Giovanni Cuffaro ( $\nabla$ giovanni.cuf@gmail.com )

Ophthalmology Unit, "Fondazione Policlinico Universitario A. Gemelli IRCCS", Rome, Italy

Pia Clara Pafundi

Fondazione Policlinico Universitario A. Gemelli IRCCS, Gemelli Generator, Rome, Italy

\section{Paola Valente}

Ophthalmology Department, Bambino Gesù IRCCS Pediatric Hospital, Rome, Italy

\section{Remo Battendieri}

Ophthalmology Unit, “Fondazione Policlinico Universitario A. Gemelli IRCCS”, Rome, Italy

\section{Luca Buzzonetti}

Ophthalmology Department, Bambino Gesù IRCCS Pediatric Hospital, Rome, Italy

\section{Roberta Mattei}

Ophthalmology Unit, “Fondazione Policlinico Universitario A. Gemelli IRCCS”, Rome, Italy

\section{Stanislao Rizzo}

Ophthalmology Unit, “Fondazione Policlinico Universitario A. Gemelli IRCCS”, Rome, Italy

\section{Gustavo Savino}

Ophthalmology Unit, “Fondazione Policlinico Universitario A. Gemelli IRCCS”, Rome, Italy

\section{Research Article}

Keywords: Eyelid Ptosis, Eyelid ptosis and Strabismus, Strabismus, Amblyopia, Refractive errors, Personalized medicine

Posted Date: January 31st, 2022

DOI: https://doi.org/10.21203/rs.3.rs-1251757/v1

License: (c) (i) This work is licensed under a Creative Commons Attribution 4.0 International License. Read Full License 


\section{Abstract}

Purpose: Aim of the study was to evaluate the prevalence and type of strabismus, ptosis and eyelid dynamic disorders features, to assess the prevalence of refractive errors, amblyopia and the association with ocular/systemic syndromes in a cohort of patients.

Methods: Retrospective observational multicenter cohort study enrolling patients with coexisting ocular motility disorders, comitant and incomitant strabismus, ptosis and dynamic eyelid disorders who have never undergone surgery.

Results: 137 out of 19.089 patients were enrolled, of which 97 with uniocular and 40 with binocular disease. Isolated congenital ptosis was observed in 84 patients. A polymalformative syndrome was present in almost one third of cases. There was a slight prevalence of esotropia; most patients were hypermetropic. In monocular disease, myopia affected prevalently older patients, who had worse ptosis margin reflex distance and levator function, and significantly higher astigmatism. Amblyopia occurred in $67.4 \%$ of the study sub-population. In monocular disease amblyopia was mild in $25.8 \%$, moderate in $24.2 \%$ and severe in $11.3 \%$. In binocular disease was mild in $25 \%$, moderate in $41.7 \%$ and severe in $16.7 \%$.

Conclusions: All patients with coexisting eyelid and ocular motility disfunctions in pediatric age need ophthalmologic and systemic evaluation to accurately assess amblyopia, refractive errors and systemic/ocupollar disorders.

\section{Introduction}

Static and dynamic eyelid disorders and ocular motility disfunctions in pediatric age are often related [1]. Frequency of strabismus among patients with eyelid disorders has been rarely reported, often only concerning congenital ptosis. Griepentrog and Mohney [2] observed strabismus in $18 \%$ of children with ptosis, Anderson and Baumgartner [3] in $36 \%$ of patients and Thapa [4] in the $27 \%$ of patients with congenital ptosis. Furthermore, this association may represent either an isolated feature or associated to several conditions such as congenital cranial dysinnervation disorders (CCDD), ocular syndromes (BPTS), orbital diseases, systemic genetic disorders, central nervous system (CNS) disorders and neurological diseases [1-4].

This association can also be related and can lead to refractive errors and amblyopia [5]. As a matter of facts, in pediatric age, it can significantly affect both visual acuity and normal binocular vision development [6].

A limited number of studies have evaluated the prevalence of eyelid and ocular motility disorders and their association with functional visual deficits and ocular/systemic syndromes. The aim of our multicenter retrospective cross-sectional study is to assess, in a cohort of pediatric patients affected by both strabismus and eyelid dynamic disorders, the prevalence and type of strabismus, the prevalence of refractive errors, the functional visual deficits (amblyopia) and the association with ocular/systemic disorders.

\section{Material And Methods}

\subsection{Study design}

This is a retrospective observational multicenter cohort study based on the data from two Italian ocular centers: the Ophthalmology Unit of the Fondazione Policlinico Universitario A. Gemelli IRCCS, Rome, Italy and the Ophthalmology Department of Bambino Gesù IRCCS Pediatric Hospital, Rome. 
The study included the medical records of all patients (age 6-16 years) with coexisting ocular motility disorders, comitant and incomitant strabismus, ptosis and eyelid dynamic disorders either in primary or in other gaze positions, who have never been previously surgically treated, afferent at the two tertiary referral centers from January 1, 2017 through December 31, 2019.

All patients with iatrogenic and traumatic eyelid and ocular motility disorders and patients previously surgically treated on eyelids or extraocular muscles were excluded.

Data from ocular and orthoptic examination, including eye motility, cycloplegic refraction, best-corrected visual acuity (BCVA) measurement, upper margin reflex distance (MRD) and levator function (LF) were collected.

MRD and LF were measured for each patient while the patient looked at an examination torch held about half a meter away. A ruler was held against the upper eyelid and the distance between the light reflex and superior eyelid margin was measured in primary position (MRD). When patients failed to show a visible light reflex, as their upper lid covered the pupil foramen, either negative or 0 values were assigned for analytical purposes. When the value was 0 , the upper lid margin covered the center of the pupil; when the value was - 1 , it outstripped the inferior pupil margin. The

LF was evaluated by measuring the excursion in millimeters of the upper eyelid between upgaze and downgaze, fixing the eyebrow.

The categories of the analyzed association were classified as "congenital isolated" and "others", and included: congenital cranial dysinnervation disorders, genetic diseases, CNS disorders and neurologic diseases, ocular syndromes and orbital diseases. The prevalence of polymalformative syndromes was further assessed. Ptosis features were classified either as bilateral and unilateral ptosis or eyelid asymmetry, whereas strabismus as esotropia, exotropia, vertical squint, and either comitant or incomitant.

Ocular alignment was assessed using prism cover-uncover tests. Cover tests were performed with fixation targets at both distance $(6 \mathrm{~m})$ and near $(33 \mathrm{~cm})$. The refractive status of all patients was evaluated both before and after cycloplegia using retinoscopy. Refractive status type (Myopia, Hyperopia, and Astigmatism: with the rule and against the rule) and size (diopters) were recorded. Spherical equivalent (SEq) was calculated as the sum of the spherical plus half of the cylindrical power. Myopia, hyperopia and astigmatism were defined as SEq<0.5 diopters (D), SEq $>0.5$ D and cylindrical error $>1.0 \mathrm{D}$, respectively. Best Correct Visual Acuity (BCVA) was assessed for right and left eye, when possible, using Lea Symbols charts [7, 8], or using ETDRS charts [9]. During visual acuity testing, all subjects wore spectacles containing the best correction.

Amblyopia was evaluated according to Pediatric Eye Disease Investigator Group (PEDIG) as mild $(20 / 25$ to < 20/40), moderate (20/40 to 20/80) and severe (20/100 to 20/400) [10]. Family history for eyelid abnormalities, oculomotor disorders and systemic/ocular diseases were also recorded.

The study was carried out with the approval from the Fondazione Policlinico Universitario A. Gemelli IRCCS Ethics Committee (Protocol ID number 0039303/20, ID:3396) and in accordance with 1976 Declaration of Helsinki and its later amendments. A written informed consent for data collection and analysis of collected data from their medical records was obtained from all patients. Photographs were obtained in selected cases with patients' permission.

\subsection{Statistical Analysis}

All variables included in the study were summarized by descriptive statistics techniques. In depth, qualitative variables were expressed as absolute and percentage frequency. As for quantitative variables, we performed the 
Shapiro-Wilk test to assess their distribution. Then, whether normally distributed, they were described as mean and standard deviation (SD), otherwise as median and interquartile range (IQR).

Between groups differences for each parameter considered (strabismus type, categories, refractive error, amblyopia, ptosis features) were assessed, as for qualitative variables, either by the Fisher Exact test or the Chi square test, with Yates correction, as appropriate. Quantitative variables were instead assessed either by one-way ANOVA or Student $t$ test, if normally distributed, otherwise either Mann Whitney U test or Kruskal-Wallis test were applied. A p value $<0.05$ was considered as statistically significant. All analyses were conducted with STATA software, version 16 (StataCorp. College Station, TX: StataCorp LLC.

\section{Results}

\subsection{General characteristics of the study cohort}

During the 3-year study period 137 out of 19.089 patients (0.72\%) afferent at the two Ophthalmological Pediatric Centers met the inclusion criteria.

In the same observation period, the total number of patients with eyelid static and dynamic disorders were 292 (1.52\%) and the total number of isolated congenital ptosis was $84(0.44 \%)$

Ninety-seven out of 137 patients had a monocular disease, affecting either right or left eye whereas in 40 cases the disease affected both eyes.

Overall median age was 12 years (IQR 7-16 yrs.). Patients were also homogeneously distributed for sex (47.4\% M vs. $52.6 \% \mathrm{~F})$, both overall and between groups.

Among systemic disorders the less prevalent were ocular syndromes and orbital diseases (6\%), whilst in almost one third there was a polymalformative syndrome associated (28.5\%). Types of strabismus were almost equally distributed, with a slight prevalence of esotropia $(37.2 \%, n=51)$. In addition, most patients were hypermetropic $(73.7 \%$, $\mathrm{n}=101)$.

Patients with disease affecting both eyes were characterized by a significantly higher strabismus angle deviation for distance $(p=0.039)$ and for near $(p=0.023)$. As well, we observed a significantly higher prevalence of comitant strabismus deviation $(p=0.021)$ and ptosis familiar history $(p=0.008)$ among subjects with both eyes affected. Levator function was indeed significantly lower in this subset of patients (median 8 vs $17 ; p<0.001$ ). All characteristics of the study population are described in Table 1.

Each characteristic of interest in the two subgroups was further separately analysed.

\subsection{Strabismus}

Strabismus was classified as follows: esotropia, exotropia and vertical squint.

Patients with monocular disease assessment showed that ptosis onset occurs significantly later in those with vertical squint (median 6 moths vs. 1 in exotropic and esotropic patients, $p=0.010$ ). An association instead emerged as for what concerns strabismus onset $(p=0.083)$, which occurred much more lately in those with vertical squint.

As regards ptosis features, all patients with vertical squint had unilateral ptosis, with the congenital one much more prevalent (83.9\% vs. $51.4 \%$ in esotropia and $75.9 \%$ in exotropia; $p=0.010$ ). 
Other relevant findings concern the refractive error value, significantly higher in those with esotropia (median 2.5 vs 1.75 in exotropia and 2 in vertical squint; $p=0.044)$, whilst BCVA was less evaluable in patients with esotropia (48.6\% vs, $65.5 \%$ vs. $77.4 \%$; $=0.047)$.

Looking at binocular disease a similar finding was observed as for vertical strabismus and an association with a younger age in patients with esotropia resulted (median 10 yrs. vs. 16 yrs in exotropia and 13 yrs in vertical squint; $\mathrm{p}=0.073$ ). Finally, patients with esotropia have shown higher values of MRD ( $3 \mathrm{~mm}$ vs $1 \mathrm{~mm}$ in the other two categories; $p=0.081$ ). All data are described in Table 2.

\subsection{Ptosis features}

We thus analysed patients according to ptosis features, either unilateral or bilateral and, within these categories, congenital ptosis or eyelid asymmetry.

As regards patients with monocular disease, we observed that vertical strabismus was significantly higher among patients with unilateral congenital ptosis $(p=0.011)$.

A significantly higher prevalence of esotropia occurred in patients with unilateral eyelid asymmetry $(p=0.010)$. In the same subgroup MRD (median $4 \mathrm{~mm}$ vs. $3 \mathrm{~mm} ; \mathrm{p}<0.001$ ) and levator function (median 18mm vs. 16mm; $p<0.001$ ) were significantly higher than among those with congenital ptosis.

Looking at patients with both eyes affected a similar finding was observed: the MRD (median 4mm vs. 1mm; $\mathrm{p}<0.001$ ) and the LF (median $18 \mathrm{~mm}$ vs. $8 \mathrm{~mm} ; \mathrm{p}<0.001$ ) were significantly higher in patients with bilateral eyelid asymmetry.

Conversely, astigmatism value was significantly lower in this subset of patients (median 0.75 vs. 2 ; $p=0.026$ ). An association instead emerged for a slightly higher refractive error in the group with eyelid asymmetry $(p=0.060)$, and for a higher strabismus angle deviation for near, in the group with congenital ptosis $(p=0.093)$. All data are reported in Table 3.

\subsection{Refractive errors}

Refractive error was classified as myopic, hypermetropic and anisometropic.

In patients with monocular disease, older patients were significantly more myopic (median 14.5 years vs. 10 hypermetric and 11 anysometric, $p=0.005$ ). Moreover, refractive error was significantly lower in myopic subjects, even though such result is affected by the small sample size of anisometropic patients.

Moreover, in this subgroup of patients, strabismus onset occurred significantly later in myopic subjects (median 6 months vs. 1, p 20.001). A comparable finding was also observed for ptosis onset. Myopic subjects were also characterized by a significantly higher prevalence of ptosis familiar history (60\% vs. $6.7 \%, p=0.001)$ and by a lower refractive error (median -3 vs. 2.5, $\mathrm{p}<0.001$ ). Conversely, both MRD (median $1 \mathrm{~mm}$ vs. $2 \mathrm{~mm}, \mathrm{p}=0.003$ ) and LF (median $3 \mathrm{~mm}$ vs. $14 \mathrm{~mm}, \mathrm{p}<0.001$ ) were significantly lower among myopic patients. A significantly higher astigmatism value among myopic patients was observed (median 3 vs. 1, p=0.003). All data are shown in Table 4.

\subsection{Diseases Categories}

For what concerns categories, we run all the categories grouped through the isolated one, in order to minimize the bias due to small sample sizes of the single subgroups. 
Looking first at monocular disease, we observed a significantly higher prevalence of associated polymalformative syndromes in the isolated category $(37.8 \%$ vs. $13 \%, p=0.026)$. A suggestive association instead emerged, with a higher prevalence of incomitant strabismus deviation type ( $56.8 \%$ vs. $34.8 \%, p=0.066)$ and a higher mild amblyopia, in patients with other diseases ( $50 \%$ vs. $17.4 \%, p=0.060)$.

Among patients with binocular disease, indeed, patients of the isolated category had a significantly higher prevalence of strabismus familiar history ( $50 \%$ vs. $5.6 \%, p=0.043)$. There was also an association with higher MRD in this subgroup (median $3 \mathrm{~mm}$ vs. $1 \mathrm{~mm}, \mathrm{p}=0.064$ ). All data are reported in Table 5.

\subsection{Amblyopia}

Sixty-two patients with monocular disease were assessed for the visual acuity vs. 24 with binocular disease. Fifty-one uncooperative patients (37.2\%) were not assessed. Amblyopia was reported in 58 out of 86 patients (67.4\%).

Thirty-eight out of 62 patients with monocular disease were diagnosed as amblyopic (61.3\%) according to Pediatric Eye Disease Investigator Group (PEDIG). Of the 62 assessed patients 16 (25.8\%) were diagnosed as Mild, 15 (24.2\%) as Moderate and 7 (11.3\%) as severe. Twenty-four patients (38.7\%) had not shown amblyopia in the affected eye.

Among the 24 patients with binocular disease assessed, amblyopia was diagnosed in $60 \%$ of the cases. Six patients (25.0\%) were diagnosed as mild, $10(41.7 \%)$ as moderate and 4 (16.7\%) as severe. Four patients (16.7\%) had not assessed as amblyopic in the affected eyes.

A severe amblyopia was assessed in $42.9 \%$ of the patients with monocular disease and the $33.3 \%$ of the patients with moderate amblyopia presented polymalformative syndromes $(p=0.015)$. All data are reported in Table 6 .

\section{Discussion}

Over a 3-year study period, this multicenter study analyzed 137 out of 19.089 patients $(0.72 \%)$ afferent at the two Ophthalmological Pediatric Centers. The overall prevalence of isolated congenital ptosis was $0.44 \%$ (84 out of 19089 patients), of whom 27 (32.1\%) were associated with ocular motility disorders. The reported prevalence of strabismus associated with congenital ptosis ranges from $18-36 \%,[1,2,3,4]$ which is a much higher prevalence than in the general population [11].

In about one third of cases there was a accompanying diagnosis of polymalformative syndrome. The binocular type shows a significantly higher prevalence of ptosis familiar history, comitant strabismus, significant higher strabismus angle deviation and lower levator function values.

Regarding strabismus type (esotropia, exotropia, vertical squint), congenital unilateral ptosis was prevalent in patients with vertical squint. Some Authors suggested that strabismus could be secondary to a disruption of binocularity by the ptotic eyelid [12].

On the other hand, as for congenital ptosis associated with vertical strabismus it would be reasonable to suppose that a prenatal insult or maldevelopment of the third cranial nerve could play an important role [13, 14]. Moreover, according to known literature, refractive error value was significantly higher in patients with esotropia [15].

As for ptosis features, we observed a significantly higher prevalence of esotropia and mild ptosis, as well as a good levator function in patients with unilateral and bilateral eyelid asymmetry. These data are mainly related to the clinical features of Type I Duane Retraction Syndrome [16]. 
With regard to refractive error features, older patients with monocular disease were significantly more myopic, and had a significantly worse ptosis MRD and LF, as well as higher astigmatism value. Several authors reported more severe refractive errors in moderate or severe ptosis. Zeng et al. reported a higher frequency of hyperopia and a lower axial length - corneal radius (AL/CR) ratio in case of severe ptosis, suggesting a delay in the growth of the eye [17]. Huo $L$ et al. instead deemed that long-standing congenital ptosis might produce myopia [18]. The refractive modifications were also related to a mechanic effect of ptotic eyelid on ocular surface that reshapes the corneal surface $[19,20]$. Our data confirm a mechanical and deprivational effect of moderate and severe eyelid ptosis, which can lead to refractive changes.

The monocular isolated association, as compared with the other categories, is significantly associated with polymalformative syndromes $(37.8 \%$ vs. $13 \%, p=0.026)$ and more often shows an incomitant strabismus deviation.

Amblyopia occurred in the $67.4 \%$ of the assessed subpopulation. In monocular disease the $25.8 \%$ was diagnosed as mild, the $24.2 \%$ as moderate and $11.3 \%$ as severe (vs. the $25 \%, 41.7 \%$ and $16.7 \%$ in those with binocular disease). Amblyopia estimated prevalence in the general population ranges from the 2.5-5.6\% [21, 22]. The reported prevalence of amblyopia in patients with ptosis and ptosis and strabismus is 7-8 times higher, and it is associated to a higher prevalence of refractive errors and to a not alternating strabismus [11, 23-25].

\section{Conclusions}

To the best of our knowledge, this is the first study investigating the relation of eyelids and ocular motility disorders. Eyelid static and dynamic disorders and ocular motility disorders are often related. These patients thus need a careful ophthalmologic and systemic evaluation due the high prevalence of amblyopia, refractive errors and systemic/ocular associated disorders.

\section{Declarations}

\section{Data Availability}

The datasets generated and/or analysed during the current study are not publicly available due the common policy of our institution, but are available from the corresponding author on reasonable request.

\section{Disclosures}

The authors declare no conflict of interests. This research did not receive any specific grant from funding agencies in public, commercial or not-for-profit sectors.

\section{References}

1. Sevel D. The origins and insertions of the extraocular muscles: Development, histologic features, and clinical significance. Trans Am Ophthalmol Soc 1986;Vol. 84:488-526.

2. Griepentrog GJ, DiehI NN, Mohney BG. Incidence and demographics of childhood ptosis. Ophthalmology 2011;118:1180-3. doi:10.1016/j.ophtha.2010.10.026

3. Anderson RL, Baumgartner SA. Strabismus in Ptosis. Arch Ophthalmol 1980;98:1062-7. doi:10.1001/archopht.1980.01020031052008 
4. Thapa R. Refractive error, strabismus and amblyopia in congenital ptosis. J Nepal Med Assoc 2010;49:43-6. doi:10.4274/tjo.40.275

5. Harrad RA, Graham CM, Collin JRO. Amblyopia and strabismus in congenital ptosis. Eye 1988;2:625-7. doi:10.1038/eye.1988.115

6. Srinagesh V, Simon JW, Meyer DR, et al. The association of refractive error, strabismus, and amblyopia with congenital ptosis. J AAPOS 2011;15:541-4. doi:10.1016/j.jaapos.2011.08.006

7. Dobson V, Clifford-Donaldson CE, Miller JM, et al. A comparison of Lea Symbol vs ETDRS letter distance visual acuity in a population of young children with a high prevalence of astigmatism. J AAPOS 2009;13:253-7. doi:10.1016/j.jaapos.2009.01.007

8. Hyvärinen L, Näsänen R, Laurinen P. New visual acuity test for pre-school children. Acta Ophthalmol (Copenh). 1980 Aug;58(4):507-11. doi: 10.1111/j.1755-3768.1980.tb08291.x.

9. Dobson V, Clifford-Donaldson CE, Miller JM, et al. A comparison of Lea Symbol vs ETDRS letter distance visual acuity in a population of young children with a high prevalence of astigmatism. J AAPOS 2009;13:253-7. doi:10.1016/j.jaapos.2009.01.007

10. Chen AM, Cotter SA. The Amblyopia Treatment Studies: Implications for Clinical Practice. Adv Ophthalmol Optom. 2016 Aug;1(1):287-305. doi: 10.1016/j.yaoo.2016.03.007.

11. Oral Y, Ozgur OR, Akcay L, et al. Congenital ptosis and amblyopia. J Pediatr Ophthalmol Strabismus 2010;47:101-4. doi:10.3928/01913913-20100308-08

12. Gusek-Schneider GC, Martus P. Stimulus deprivation amblyopia in human congenital ptosis: a study of 100 patients. Strabismus 2000;8:261-70. doi:10.1076/STRA.8.4.261.687

13. Vivian AJ. Congenital fibrosis of the extra-ocular muscles (CFEOM) and the cranial dysinnervation disorders. Eye (Lond) 2020;34:251-5. doi:10.1038/S41433-019-0700-Z

14. Parsa CF, Robert MP. Thromboembolism and congenital malformations: from Duane syndrome to thalidomide embryopathy. JAMA Ophthalmo/ 2013;131:439-47. doi:10.1001/JAMAOPHTHALMOL.2013.1111

15. Tang SM, Chan RYT, Bin Lin S, et al. Refractive Errors and Concomitant Strabismus: A Systematic Review and Meta-analysis. Sci Rep 2016;6. doi:10.1038/SREP35177

16. Barry BJ, Whitman MC, Hunter DG, et al. Duane Syndrome. Ocul Dis Mech Manag 2019;:438-44. doi:10.1016/B978-0-7020-2983-7.00057-7

17. Zeng $X Y$, Wang JX, Qi XL, et al. Effects of congenital ptosis on the refractive development of eye and vision in children. Int J Ophthalmol 2020;13:1788. doi:10.18240/IJO.2020.11.16

18. Huo L, Cui D, Yang X, et al. A retrospective study: form-deprivation myopia in unilateral congenital ptosis. Clin Exp Optom 2012;95:404-9. doi:10.1111/J.1444-0938.2012.00716.X

19. Assadi F, Narayana S, Yadalla D, et al. Effect of congenital ptosis correction on corneal topography-A prospective study. Indian J Ophthalmo/2021;69:1527. doi:10.4103/IJO.IJO_2650_20

20. Savino G, Battendieri R, Riso M, et al. Corneal Topographic Changes After Eyelid Ptosis Surgery. Cornea 2016;35:501-5. doi:10.1097/ICO.0000000000000729

21. Elflein HM. [Amblyopia. Epidemiology, causes and risk factors]. Ophthalmologe 2016;113:283-8. doi:10.1007/S00347-016-0247-3

22. Tailor V, Bossi M, Greenwood JA, et al. Childhood amblyopia: current management and new trends. Br Med Bull 2016;119:75-86. doi:10.1093/BMB/LDW030 
23. Wang Y, Xu Y, Liu X, et al. Amblyopia, Strabismus and Refractive Errors in Congenital Ptosis: a systematic review and meta-analysis. Sci Rep 2018;8. doi:10.1038/S41598-018-26671-3

24. Harrad RA, Graham CM, Collin JRO. Amblyopia and strabismus in congenital ptosis. Eye (Lond) 1988;2 ( Pt 6):625-7. doi:10.1038/EYE.1988.115

25. Srinagesh V, Simon JW, Meyer DR, et al. The association of refractive error, strabismus, and amblyopia with congenital ptosis. J AAPOS Off Publ Am Assoc Pediatr Ophthalmol Strabismus 2011;15:541-4. doi:10.1016/J.JAAPOS.2011.08.006

\section{Tables}

Table 1. General characteristics of the study population $(n=137)$. 


\begin{tabular}{|c|c|c|c|c|}
\hline & $\begin{array}{l}\text { Overall } \\
(n=137)\end{array}$ & $\begin{array}{l}\text { Monocular } \\
\text { Disease }(n=97)\end{array}$ & $\begin{array}{l}\text { Bi-ocular Disease } \\
(n=40)\end{array}$ & p \\
\hline Age (yrs.) & $12[7-16]$ & $12[7-16]$ & $13[6.5-16]$ & 0.827 \\
\hline Sex & & & & 0.701 \\
\hline M & $65(47.4)$ & $45(46.4)$ & $20(50)$ & \\
\hline$F$ & $72(52.6)$ & $52(53.6)$ & $20(50)$ & \\
\hline Categories & & & & 0.004 \\
\hline Congenital cranial dysinnervation disorders & $25(18.2)$ & $23(23.7)$ & $2(5)$ & \\
\hline Isolated & $27(19.7)$ & $23(23.7)$ & $4(10)$ & \\
\hline Genetic & $37(27)$ & $23(23.7)$ & $14(35)$ & \\
\hline CNS disorders and neurological diseases & $38(27.7)$ & $24(24.7)$ & $14(35)$ & \\
\hline Ocular syndromes and orbital diseases & $10(7.3)$ & $4(4.1)$ & $6(15)$ & \\
\hline Categories & & & & 0.110 \\
\hline Isolated & $27(19.7)$ & $23(23.7)$ & $4(10)$ & \\
\hline Others & $110(80.3)$ & $74(76.3)$ & $36(90)$ & \\
\hline Polymalphormative syndromes associated & $39(28.5)$ & $31(32)$ & $8(20)$ & 0.158 \\
\hline Strabismus type & & & & 0.842 \\
\hline Esotropia & $51(37.2)$ & $37(38.1)$ & $14(35)$ & \\
\hline Exotropia & $43(31.4)$ & $29(29.9)$ & $14(35)$ & \\
\hline Vertical squint & $43(31.4)$ & $31(32)$ & $12(30)$ & \\
\hline Strabismus angle deviation distance & $14[6-30]$ & $14[4-25]$ & $20[10-30]$ & 0.039 \\
\hline Strabismus angle deviation near & $14[6-30]$ & $14[6-25]$ & $20.5[10-33.75]$ & 0.023 \\
\hline Vertical strabismus & $0[0-5]$ & $0[0-5]$ & $0[0-3.75]$ & 0.771 \\
\hline Strabismus onset & $21-6]$ & $2[1-14.3]$ & $1[1-6]$ & 0.311 \\
\hline Strabismus familiar history & $7(5.1)$ & $3(3.1)$ & $4(10)$ & 0.214 \\
\hline Strabismus deviation type & & & & 0.021 \\
\hline Comitant & $75(54.7)$ & $47(48.5)$ & $28(70)$ & \\
\hline Incomitant & $62(45.3)$ & $50(51.5)$ & $12(30)$ & \\
\hline Ptosis familiar history & $12(8.8)$ & $4(4.1)$ & $8(20)$ & 0.008 \\
\hline Ptosis features & & & & $<0.001$ \\
\hline Bilateral-ptosis & $34(24.8)$ & - & $34(85)$ & \\
\hline Bilateral eyelid asymmetry & $6(4.4)$ & - & $6(15)$ & \\
\hline Unilateral-ptosis & $67(48.9)$ & $67(69.1)$ & - & \\
\hline
\end{tabular}




\begin{tabular}{|c|c|c|c|c|}
\hline Unilateral eyelid asymmetry & $30(21.9)$ & $30(30.9)$ & - & \\
\hline Ptosis MRD (mm) & $3[1-4]$ & $3[2-4]$ & $1[1-3]$ & $<0.001$ \\
\hline Ptosis onset & $2[1-6]$ & $2[1-6]$ & $1[1-6]$ & 0.715 \\
\hline Levator function & $16[10-18]$ & $17[14-18]$ & $8[4.25-15]$ & $<0.001$ \\
\hline Refractive error & & & & 0.658 \\
\hline Myopic & $34(24.8)$ & $24(24.7)$ & $10(25)$ & \\
\hline Hypermetropic & $101(73.7)$ & $71(73.2)$ & $30(75)$ & \\
\hline Anisometropic & $2(1.5)$ & $2(2.1)$ & - & \\
\hline Refractive error & $2.25[-0.5-3]$ & $2.25[-0.5-3.13]$ & $2.25[-0.38-2.94]$ & 0.589 \\
\hline Amblyopia* & & & & 0.187 \\
\hline None & $28(32.6)$ & $24(38.7)$ & $4(16.7)$ & \\
\hline Mild & $22(25.6)$ & $16(25.8)$ & $6(25)$ & \\
\hline Moderate & $25(29.1)$ & $15(24.2)$ & $10(41.7)$ & \\
\hline Severe & $11(11.8)$ & $7(11.3)$ & $4(16.7)$ & \\
\hline Fixing eye & & & & 0.581 \\
\hline Right & $60(43.8)$ & $44(45.4)$ & $16(40)$ & \\
\hline Left & $44(32.1)$ & $32(33)$ & $12(30)$ & \\
\hline Alternative fixation & $33(24.1)$ & $21(21.6)$ & $12(30)$ & \\
\hline Is astigmatism evaluable? & $79(57.7)$ & $57(58.8)$ & $22(55)$ & 0.685 \\
\hline Astigmatism value & $0.5[0-1]$ & $0.5[0-1]$ & $0.5[0-2]$ & 0.517 \\
\hline Is BCVA evaluable? & $85(62)$ & $61(62.9)$ & $24(60)$ & 0.752 \\
\hline BCVA Ptosis & $0.1[0-0.45]$ & 1. $[0-0.35]$ & $0.3[0.1-0.68]$ & 0.040 \\
\hline \multicolumn{5}{|c|}{$\begin{array}{l}\text { M: Male; F: Female; CNS: Central Nervous System; MRD: Margin Reflex Distance; BCVA: Best Corrected Visual } \\
\text { Acuity; } \\
\text { * Others: congenital cranial dysinnervation disorders, Genetic, CNS disorders/neurological diseases, Ocular } \\
\text { syndromes/orbital diseases. ** Qualitative variables are expressed as absolute and percentage frequency } \\
\text { quantitative data as median and interquartile range (IQR). Significant data are in bold, suggestive p-values in } \\
\text { italic. }\end{array}$} \\
\hline
\end{tabular}

Table 2. Association between strabismus type and general and clinical characteristics in the study cohort, according to patients' subgroups $(n=137)$. 


\begin{tabular}{|c|c|c|c|c|c|c|c|c|}
\hline & \multicolumn{4}{|c|}{ MONOCULAR DISEASE $(n=97)$} & \multicolumn{4}{|c|}{ BINOCULAR DISEASE $(n=40)$} \\
\hline & $\begin{array}{l}\text { Esotropia } \\
(n=37)\end{array}$ & $\begin{array}{l}\text { Exotropia } \\
(n=29)\end{array}$ & $\begin{array}{l}\text { Vertical } \\
\text { squint } \\
(n=31)\end{array}$ & p & $\begin{array}{l}\text { Esotropia } \\
(n=14)\end{array}$ & $\begin{array}{l}\text { Exotropia } \\
(n=14)\end{array}$ & $\begin{array}{l}\text { Vertical } \\
\text { squint } \\
(n=12)\end{array}$ & $\mathbf{p}$ \\
\hline Age (yrs.) & $\begin{array}{l}12[7- \\
16]\end{array}$ & $\begin{array}{l}10[7- \\
16]\end{array}$ & $\begin{array}{l}12 \\
{[10-} \\
15]\end{array}$ & 0.577 & $\begin{array}{l}10[6- \\
14]\end{array}$ & $\begin{array}{l}16[3- \\
17]\end{array}$ & $\begin{array}{l}13 \\
{[12-} \\
17]\end{array}$ & 0.073 \\
\hline Sex & & & & 0.713 & & & & 0.123 \\
\hline M & $19(51.4)$ & $12(41.4)$ & 14 & & $10(71.4)$ & $6(42.9)$ & 4 & \\
\hline$F$ & 18 (48.6) & $17(58.6)$ & $\begin{array}{l}17 \\
(54.8)\end{array}$ & & $4(28.6)$ & $8(57.1)$ & $\begin{array}{l}8 \\
(66.7)\end{array}$ & \\
\hline Categories & & & & 0.353 & & & & 0.433 \\
\hline Isolated & $6(16.2)$ & $9(31)$ & 8 & & $2(14.3)$ & $0(0.0)$ & 2 & \\
\hline Others* & 31 (83.8) & $20(69)$ & $\begin{array}{l}23 \\
(74.2)\end{array}$ & & $12(85.7)$ & $14(100)$ & $\begin{array}{l}10 \\
(83.3)\end{array}$ & \\
\hline $\begin{array}{l}\text { Polymalphormative } \\
\text { syndromes } \\
\text { associated }\end{array}$ & $13(35.1)$ & $9(31)$ & $9(29)$ & 0.858 & $2(14.3)$ & $2(14.3)$ & $\begin{array}{l}4 \\
(33.3)\end{array}$ & 0.427 \\
\hline $\begin{array}{l}\text { Strabismus angle } \\
\text { deviation distance }\end{array}$ & $\begin{array}{l}15[5- \\
22.5]\end{array}$ & $\begin{array}{l}12[5- \\
27.5]\end{array}$ & $\begin{array}{l}12[0- \\
25]\end{array}$ & 0.660 & $\begin{array}{l}20[10- \\
25]\end{array}$ & $\begin{array}{l}20[8- \\
30]\end{array}$ & $\begin{array}{l}20[10 \\
-35]\end{array}$ & 0.936 \\
\hline $\begin{array}{l}\text { Strabismus angle } \\
\text { deviation near }\end{array}$ & $\begin{array}{l}14[6- \\
25]\end{array}$ & $\begin{array}{l}14[7- \\
19]\end{array}$ & $\begin{array}{l}10[0- \\
20]\end{array}$ & 0.296 & $\begin{array}{l}25[10- \\
30]\end{array}$ & $\begin{array}{l}15[8- \\
30]\end{array}$ & $\begin{array}{l}23[10 \\
-55]\end{array}$ & 0.676 \\
\hline Vertical strabismus & $0[0-0]$ & $0[0-0]$ & $\begin{array}{l}10[5- \\
16]\end{array}$ & $<0.001$ & $0[0-0]$ & $0[0-0]$ & $\begin{array}{l}18[5- \\
40]\end{array}$ & $<0.001$ \\
\hline Strabismus onset & $2[1-6]$ & $\begin{array}{l}2[1- \\
34.8]\end{array}$ & $\begin{array}{l}6[1- \\
48]\end{array}$ & 0.083 & $1[1-6]$ & $\begin{array}{l}1[1- \\
108]\end{array}$ & $\begin{array}{l}4[1- \\
6]\end{array}$ & 0.746 \\
\hline $\begin{array}{l}\text { Strabismus } \\
\text { familiar history }\end{array}$ & - & $2(6.9)$ & $1(3.2)$ & 0.275 & $2(14.3)$ & $2(14.3)$ & $0(0.0)$ & 0.524 \\
\hline $\begin{array}{l}\text { Ptosis familiar } \\
\text { history }\end{array}$ & $1(2.7)$ & $2(6.9)$ & $1(3.2)$ & 0.665 & $2(14.3)$ & $6(42.9)$ & $0(0.0)$ & 0.019 \\
\hline Strabismus & & & & 0.181 & & & & 0.265 \\
\hline Concomitant & $17(45.9)$ & $18(62.1)$ & $\begin{array}{l}12 \\
(38.7)\end{array}$ & & $12(85.7)$ & $8(57.1)$ & $\begin{array}{l}8 \\
(66.7)\end{array}$ & \\
\hline Incomitant & $20(54.1)$ & $11(37.9)$ & $\begin{array}{l}19 \\
(61.3)\end{array}$ & & $2(14.3)$ & $6(42.9)$ & $\begin{array}{l}4 \\
(33.3)\end{array}$ & \\
\hline Ptosis features & - & - & - & 0.010 & & & & 0.182 \\
\hline Bilateral ptosis & - & - & - & & $10(71.4)$ & $12(85.7)$ & 12 & \\
\hline $\begin{array}{l}\text { Bilateral eyelid } \\
\text { asymmetry }\end{array}$ & $19(51.4)$ & $22(75.9)$ & $\begin{array}{l}26 \\
(83.9)\end{array}$ & & $4(28.6)$ & $2(14.3)$ & $0(0.0)$ & \\
\hline Unilateral ptosis & 18 (48.6) & $7(24.1)$ & $\begin{array}{l}5 \\
(16.1)\end{array}$ & & $\begin{array}{l}- \\
-\end{array}$ & - & - & \\
\hline
\end{tabular}




\begin{tabular}{|c|c|c|c|c|c|c|c|c|}
\hline Ptosis MRD (mm) & $3[2-4]$ & $3[2-4]$ & $\begin{array}{l}3[1- \\
4]\end{array}$ & 0.121 & $3[1-4]$ & $1[1-3]$ & $\begin{array}{l}1[1- \\
2]\end{array}$ & 0.081 \\
\hline Ptosis onset & $1[1-4]$ & $\begin{array}{l}2[1- \\
17.3]\end{array}$ & $\begin{array}{l}6[1- \\
60]\end{array}$ & 0.010 & $1[1-6]$ & $\begin{array}{l}1[1- \\
108]\end{array}$ & $\begin{array}{l}4[1- \\
6]\end{array}$ & 0.750 \\
\hline Levator function & $\begin{array}{l}18[15- \\
18.5]\end{array}$ & $\begin{array}{l}16[12- \\
18]\end{array}$ & $\begin{array}{l}18[14 \\
-18]\end{array}$ & 0.489 & $\begin{array}{l}15[3- \\
16]\end{array}$ & $8[4-14]$ & $\begin{array}{l}8[5- \\
14]\end{array}$ & 0.709 \\
\hline Refractive error & & & & 0.242 & & & & 0.811 \\
\hline Myopic & $5(13.5)$ & $8(27.6)$ & \multirow{2}{*}{$\begin{array}{l}11 \\
(35.5)\end{array}$} & & $4(28.6)$ & $4(28.6)$ & \multirow{2}{*}{$\begin{array}{l}2 \\
(16.7)\end{array}$} & \\
\hline Hypermetropic & $31(83.8)$ & $21(72.4)$ & & & $10(71.4)$ & $10(71.4)$ & & \\
\hline Anisometropic & $1(2.7)$ & - & $\begin{array}{l}19 \\
(61.3)\end{array}$ & & $0(0.0)$ & $0(0.0)$ & $\begin{array}{l}10 \\
(83.3)\end{array}$ & \\
\hline & & & $1(3.2)$ & & & & \multicolumn{2}{|l|}{$0(0.0)$} \\
\hline Refractive error & $\begin{array}{l}2.5[2- \\
4]\end{array}$ & $\begin{array}{l}1.75 \\
{[-0.13-} \\
3]\end{array}$ & $\begin{array}{l}2[-1- \\
3]\end{array}$ & 0.044 & $\begin{array}{l}2.55 \\
{[-4.00-} \\
7.00]\end{array}$ & $\begin{array}{l}1.50 \\
{[-2.00-} \\
2.75]\end{array}$ & $\begin{array}{l}1.75 \\
{[1.0-} \\
2.5]\end{array}$ & 0.391 \\
\hline Amblyopia** & & & & 0.597 & & & & - \\
\hline None & $6(31.6)$ & $6(31.6)$ & $12(50)$ & & $2(25.0)$ & $2(25.0)$ & $0(0.0)$ & \\
\hline Mild & $7(36.8)$ & $4(21.1)$ & \multirow[t]{2}{*}{$\begin{array}{l}5 \\
(20.8)\end{array}$} & & $0(0.0)$ & $2(25.0)$ & \multirow[t]{2}{*}{$\begin{array}{l}4 \\
(50.0)\end{array}$} & \\
\hline Moderate & $5(26.3)$ & $6(31.6)$ & & & $6(75.0)$ & $4(50.0)$ & & \\
\hline Severe & $1(5.3)$ & $3(15.8)$ & $\begin{array}{l}(16.7) \\
3 \\
(12.5)\end{array}$ & & $0(0.0)$ & $0(0.0)$ & $\begin{array}{l}4 \\
(50.0)\end{array}$ & \\
\hline
\end{tabular}

\section{Fixing eye}

$\begin{array}{llll}\text { Right } & 17(45.9) & 12(41.4) & 15 \\ \text { Left } & 11(29.7) & 11(37.9) & (48.4) \\ & & & 10\end{array}$

Alternate fixation
$9(24.3) \quad 6(20.7) \quad(32.3)$

(19.4)
0.045

0.949

$\begin{array}{lll}10(71.4) & 2(14.3) & 4 \\ 2(14.3) & 6(42.9) & (33.3 \\ 2(14.3) & 6(42.9) & (33.3 \\ & & 4\end{array}$

4

\begin{tabular}{|c|c|c|c|c|c|c|c|c|}
\hline $\begin{array}{l}\text { Is astigmatism } \\
\text { evaluable? }\end{array}$ & $18(48.6)$ & $19(65.5)$ & $\begin{array}{l}20 \\
(64.5)\end{array}$ & 0.282 & $10(71.4)$ & $6(42.9)$ & $\begin{array}{l}6 \\
(50.0)\end{array}$ & 0.289 \\
\hline Astigmatism value & $\begin{array}{l}0.25[0- \\
1]\end{array}$ & $\begin{array}{l}0.5[0- \\
1]\end{array}$ & $\begin{array}{l}0.75[0 \\
-1]\end{array}$ & 0.726 & $\begin{array}{l}1.75 \\
{[1.00-} \\
2.00]\end{array}$ & $\begin{array}{l}1.00 \\
{[1.00-} \\
3.00]\end{array}$ & $\begin{array}{l}1.75 \\
{[0.5-} \\
2.5]\end{array}$ & 0.880 \\
\hline Is BCVA evaluable? & $18(48.6)$ & $19(65.5)$ & $\begin{array}{l}24 \\
(77.4)\end{array}$ & 0.047 & $8(57.1)$ & $8(57.1)$ & $\begin{array}{l}8 \\
(66.7)\end{array}$ & 0.848 \\
\hline BCVA Ptosis & $\begin{array}{l}0.1[0- \\
0.3]\end{array}$ & $\begin{array}{l}0.2[0- \\
0.4]\end{array}$ & $\begin{array}{l}0.05[0 \\
-0.38]\end{array}$ & 0.487 & $\begin{array}{l}0.45 \\
{[0.15-} \\
0.60]\end{array}$ & $\begin{array}{l}0.20 \\
{[0.05-} \\
0.55]\end{array}$ & $\begin{array}{l}0.45 \\
{[0.1-} \\
0.95]\end{array}$ & 0.790 \\
\hline
\end{tabular}

M: Male; F: Female; MRD: Margin Reflex Distance; BCVA: Best Corrected Visual Acuity; 
* Others: congenital cranial dysinnervation disorders, Genetic, CNS disorders/neurological diseases, Ocular syndromes/orbital diseases. ${ }^{* \star}$ Amblyopia was analysed on the subgroup of patients for which information was available. *** Qualitative variables are expressed as absolute and percentage frequency quantitative data as median and interquartile range (IQR). Significant data are in bold, suggestive p-values in italic.

Table 3. Association between ptosis features and general and clinical characteristics in the study cohort, according to patients' subgroups ( $n=137)$. 


\begin{tabular}{|c|c|c|c|c|c|c|}
\hline & \multicolumn{3}{|c|}{ MONOCULAR DISEASE $(n=97)$} & \multicolumn{3}{|c|}{ BINOCULAR DISEASE $(n=40)$} \\
\hline & $\begin{array}{l}\text { Unilateral } \\
\text { congenital } \\
\text { ptosis } \\
(n=67)\end{array}$ & $\begin{array}{l}\begin{array}{l}\text { Unilateral } \\
\text { eyelid }\end{array} \\
\text { asymmetry } \\
(n=30)\end{array}$ & $\mathbf{p}$ & $\begin{array}{l}\text { Bilateral } \\
\text { congenital } \\
\text { ptosis } \\
(n=34)\end{array}$ & $\begin{array}{l}\text { Bilateral eyelid } \\
\text { asymmetry } \\
(n=6)\end{array}$ & $\mathbf{p}$ \\
\hline Age (yrs.) & $12[8-16]$ & $10[7-15]$ & 0.159 & $13[6-16]$ & $14[10-16]$ & 0.648 \\
\hline Sex & & & 0.398 & & & 0.661 \\
\hline M & $33(49.3)$ & $12(40)$ & & $16(47.1)$ & $4(66.7)$ & \\
\hline$F$ & $34(50.7)$ & $18(60)$ & & $18(52.9)$ & $2(33.3)$ & \\
\hline Categories & & & 0.275 & & & 1.000 \\
\hline Isolated & $18(26.9)$ & $5(16.7)$ & & $4(11.8)$ & - & \\
\hline Others* & $49(73.1)$ & $25(83.3)$ & & $30(88.2)$ & $6(100)$ & \\
\hline $\begin{array}{l}\text { Polymalphormative } \\
\text { syndromes associated }\end{array}$ & $24(35.8)$ & $7(23.3)$ & 0.223 & $6(17.6)$ & $2(33.3)$ & 0.580 \\
\hline Strabismus type & & & 0.010 & & & 0.182 \\
\hline Esotropia & $19(28.4)$ & $18(60)$ & & $10(29.4)$ & $4(66.7)$ & \\
\hline Exotropia & $22(32.8)$ & $7(23.3)$ & & $12(35.3)$ & $2(33.3)$ & \\
\hline Vertical squint & $26(38.8)$ & $5(16.7)$ & & $12(35.3)$ & $0(0.0)$ & \\
\hline $\begin{array}{l}\text { Strabismus angle } \\
\text { deviation distance }\end{array}$ & $12[4-25]$ & $\begin{array}{l}14[5.5- \\
20]\end{array}$ & 0.888 & $25[10-30]$ & $10[6-16]$ & 0.047 \\
\hline $\begin{array}{l}\text { Strabismus angle } \\
\text { deviation near }\end{array}$ & $14[6-25]$ & $\begin{array}{l}13[6- \\
21.3]\end{array}$ & 0.876 & $30[10-35]$ & $10[8-16]$ & 0.093 \\
\hline Vertical strabismus & $0[0-8]$ & $0[0-0]$ & 0.011 & $0[0-5]$ & $0[0-0]$ & 0.135 \\
\hline Strabismus onset & $2[1-30]$ & $2[1-6]$ & 0.240 & $1[1-6]$ & $1[1-108]$ & 0.933 \\
\hline $\begin{array}{l}\text { Strabismus familiar } \\
\text { history }\end{array}$ & $2(3)$ & $1(3.3)$ & 0.927 & $4(11.8)$ & $0(0.0)$ & 1.000 \\
\hline Strabismus deviation type & & & 0.500 & & & 0.153 \\
\hline Comitant & $34(50.7)$ & $13(43.3)$ & & $22(64.7)$ & $6(100)$ & \\
\hline Incomitant & $33(49.3)$ & $17(56.7)$ & & $12(35.3)$ & $0(0.0)$ & \\
\hline Ptosis familiar history & $4(6)$ & - & 0.172 & $8(23.5)$ & $0(0.0)$ & 0.318 \\
\hline Ptosis MRD (mm) & $3[2-3]$ & $4[3-4]$ & $<0.001$ & $1[1-2]$ & $4[4-4]$ & $<0.001$ \\
\hline Ptosis onset & $2[1-13]$ & $1.5[1-6]$ & 0.310 & $1[1-6]$ & $1[1-108]$ & 0.800 \\
\hline Levator function & $\begin{array}{l}16[12- \\
18]\end{array}$ & $\begin{array}{l}18[17.8- \\
19]\end{array}$ & $<0.001$ & $8[4-14]$ & 18 [16 - 18] & $<0.001$ \\
\hline Refractive error & & & 0.457 & & & 0.307 \\
\hline Myopic & $18(26.9)$ & $6(20)$ & & $10(29.4)$ & $0(0.0)$ & \\
\hline
\end{tabular}




\begin{tabular}{|c|c|c|c|c|c|c|}
\hline Hypermetropic & $47(70.1)$ & $24(80)$ & & $24(70.6)$ & $6(100)$ & \\
\hline Anisometropic & $2(3)$ & - & & $0(0.0)$ & $0(0.0)$ & \\
\hline Refractive error & $\begin{array}{l}2.25[-0.5 \\
-3]\end{array}$ & $\begin{array}{l}2.25[1- \\
3.25]\end{array}$ & 0.504 & $\begin{array}{l}1.625[-0.50- \\
2.75]\end{array}$ & $\begin{array}{l}2.55[2.25- \\
6.50]\end{array}$ & 0.060 \\
\hline Amblyopia** & & & 0.699 & & & n.a. \\
\hline None & $16(37.2)$ & $8(42.1)$ & & $0(0.0)$ & $4(100)$ & \\
\hline Mild & $10(23.3)$ & $6(31.6)$ & & $6(30.0)$ & $0(0.0)$ & \\
\hline Moderate & $11(25.6)$ & $4(21.1)$ & & $10(50.0)$ & $0(0.0)$ & \\
\hline Severe & $6(14)$ & $1(5.3)$ & & $4(20.0)$ & $0(0.0)$ & \\
\hline Fixing eye & & & 0.167 & & & 0.102 \\
\hline Right & $33(49.3)$ & $11(36.7)$ & & $14(41.2)$ & $2(33.3)$ & \\
\hline Left & $23(34.3)$ & $9(30)$ & & $8(23.5)$ & $4(66.7)$ & \\
\hline Alternate fixation & $11(16.4)$ & $10(33.3)$ & & $12(35.3)$ & $0(0.0)$ & \\
\hline Is astigmatism evaluable? & $41(61.2)$ & $16(53.3)$ & 0.467 & $18(52.9)$ & $4(66.7)$ & 0.673 \\
\hline Astigmatism value & $0.5[0-1]$ & $0.4[0-1]$ & 0.523 & $2.0[1.0-3.0]$ & $0.75[0.5-1.0]$ & 0.026 \\
\hline Is BCVA evaluable? & $43(64.2)$ & $18(60)$ & 0.694 & $20(58.8)$ & $4(66.7)$ & 1.000 \\
\hline BCVA Ptosis, median [IQR] & $\begin{array}{l}0.1[0- \\
0.4]\end{array}$ & $\begin{array}{l}0.1[0- \\
0.3]\end{array}$ & 0.624 & $0.5[0.1-0.7]$ & - & n.a. \\
\hline \multicolumn{7}{|c|}{$\begin{array}{l}\text { M: Male; F: Female; MRD: Margin Reflex Distance; BCVA: Best Corrected Visual Acuity; n.a.: not applicable. } \\
\text { * Others: congenital cranial dysinnervation disorders, Genetic, CNS disorders/neurological diseases, Ocular } \\
\text { syndromes/orbital diseases. ** Amblyopia was analysed on the subgroup of patients for which information was } \\
\text { available. *** Qualitative variables are expressed as absolute and percentage frequency quantitative data as } \\
\text { median and interquartile range (IQR). Significant data are in bold, suggestive p-values in italic. }\end{array}$} \\
\hline
\end{tabular}

Table 4. Association between type of refractive error and general and clinical characteristics in the study cohort, according to patients' subgroups $(n=137)$. 


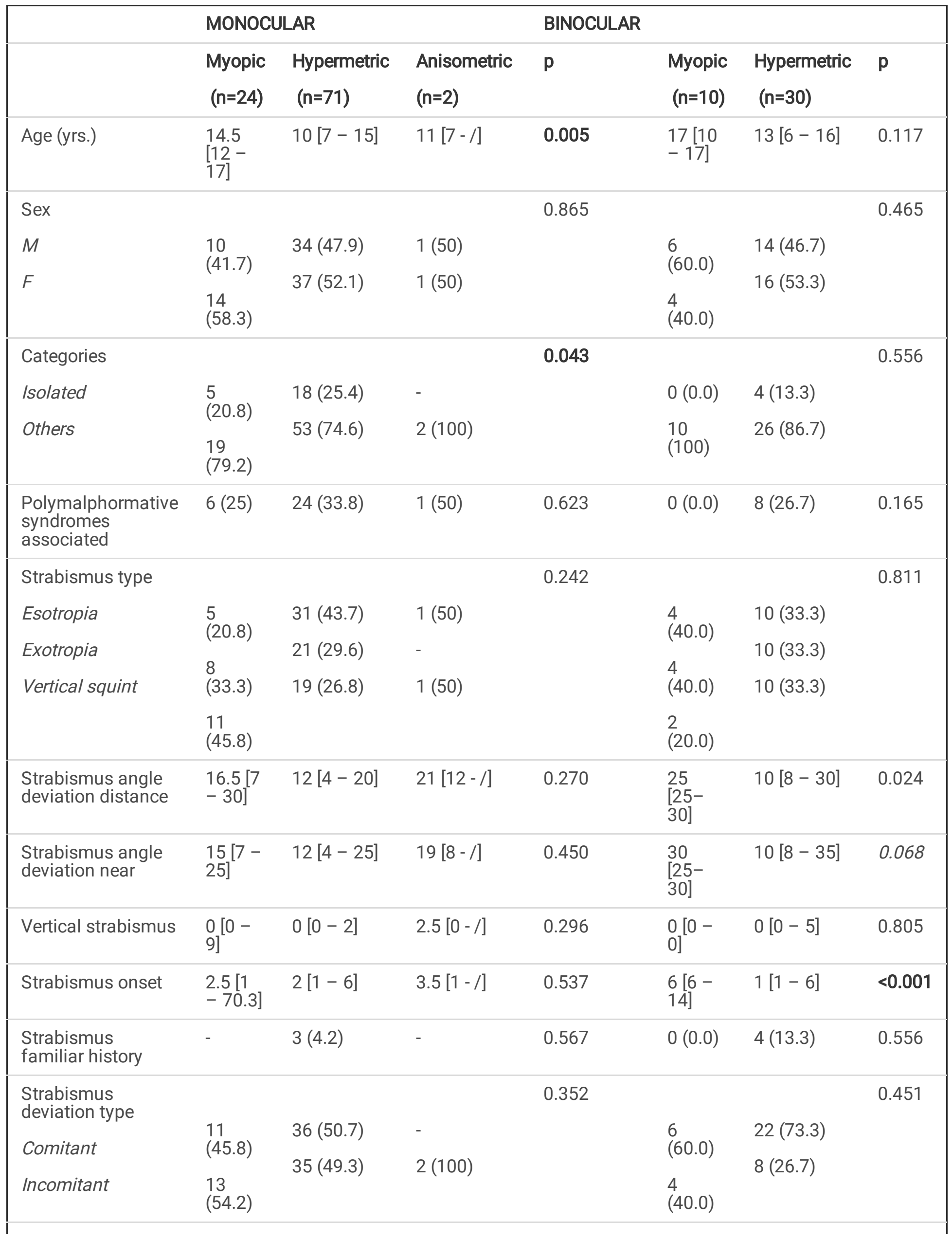




\begin{tabular}{|c|c|c|c|c|c|c|c|}
\hline $\begin{array}{l}\text { Ptosis familiar } \\
\text { history }\end{array}$ & $1(4.2)$ & $3(4.2)$ & - & 0.957 & $\begin{array}{l}6 \\
(60.0)\end{array}$ & $2(6.7)$ & 0.001 \\
\hline \multicolumn{4}{|l|}{ Ptosis features } & \multicolumn{3}{|l|}{0.457} & 0.307 \\
\hline Bilateral-ptosis & - & - & - & & $\begin{array}{l}10 \\
(100)\end{array}$ & & \\
\hline \multirow{2}{*}{$\begin{array}{l}\text { Bilateral eyelid } \\
\text { asymmetry }\end{array}$} & - & - & - & & \multirow{2}{*}{$0(0.0)$} & $6(20.0)$ & \\
\hline & \multirow{2}{*}{$6(25)$} & $47(66.2)$ & \multicolumn{2}{|l|}{$2(100)$} & & - & \\
\hline $\begin{array}{l}\text { Unilateral eyelid } \\
\text { asymmetry }\end{array}$ & & $24(33.8)$ & - & & - & - & \\
\hline Ptosis MRD (mm) & $\begin{array}{l}3[2- \\
4]\end{array}$ & $3[2-4]$ & $2[1-/]$ & 0.561 & $\begin{array}{l}1[0- \\
1]\end{array}$ & $2[1-4]$ & 0.003 \\
\hline Ptosis onset & $\begin{array}{l}2[1- \\
68.4]\end{array}$ & $2[1-6]$ & $3.5[1-/]$ & 0.483 & $\begin{array}{l}6[6- \\
138]\end{array}$ & $1[1-6]$ & $<0.001$ \\
\hline Levator function & $\begin{array}{l}18[16 \\
-18]\end{array}$ & $\begin{array}{l}16 \text { è14 - } \\
18]\end{array}$ & $18[18-18]$ & 0.293 & $\begin{array}{l}3[3- \\
4]\end{array}$ & $14[7-16]$ & $<0.001$ \\
\hline Refractive error & $\begin{array}{l}-1 \\
{[-2.25} \\
--0.5]\end{array}$ & $\begin{array}{l}2.75[2- \\
3.5]\end{array}$ & $-6.5[-11-/]$ & $<0.001$ & $\begin{array}{l}-3[-4- \\
-2]\end{array}$ & $\begin{array}{l}2.50[1.75- \\
3.25]\end{array}$ & $<0.001$ \\
\hline \multicolumn{2}{|l|}{ Amblyopia } & & & \multirow[t]{5}{*}{0.141} & & & - \\
\hline None & $9(45)$ & $15(36.6)$ & - & & $0(0.0)$ & $4(28.6)$ & \\
\hline Mild & $4(20)$ & 15 (36.6) & - & & $0(0.0)$ & $6(42.9)$ & \\
\hline Moderate & $4(20)$ & $11(26.8)$ & - & & 8 & $2(14.3)$ & \\
\hline Severe & $3(15)$ & $3(7.3)$ & $1(50)$ & & $\begin{array}{l}2 \\
(20.0)\end{array}$ & $2(14.3)$ & \\
\hline \multicolumn{4}{|l|}{ Fixing eye } & \multirow[t]{5}{*}{0.500} & & & 0.603 \\
\hline Right & $\begin{array}{l}8 \\
(33.3)\end{array}$ & $35(49.3)$ & $1(50)$ & & $\begin{array}{l}4 \\
(40.0)\end{array}$ & $12(40.0)$ & \\
\hline Left & & $20(28.2)$ & $1(50)$ & & & $8(26.7)$ & \\
\hline \multirow[t]{2}{*}{ Alternate fixation } & $(45.8)$ & $16(22.5)$ & - & & $\begin{array}{l}4 \\
(40.0)\end{array}$ & 10 (33.3) & \\
\hline & $\begin{array}{l}5 \\
(20.8)\end{array}$ & & & & $\begin{array}{l}2 \\
(20.0)\end{array}$ & & \\
\hline $\begin{array}{l}\text { Is astigmatism } \\
\text { evaluable? } \mathrm{n}(\%)\end{array}$ & $\begin{array}{l}14 \\
(58.3)\end{array}$ & $41(57.7)$ & $2(100)$ & 0.488 & $\begin{array}{l}6 \\
(60.0)\end{array}$ & $16(53.3)$ & 1.000 \\
\hline Astigmatism value. & $\begin{array}{l}0.4[0 \\
-1.2]\end{array}$ & $0.5[0-1]$ & $1.75[1.5-/]$ & 0.158 & $\begin{array}{l}3[2- \\
3]\end{array}$ & $\begin{array}{l}1.00[0.75- \\
1.75]\end{array}$ & 0.003 \\
\hline $\begin{array}{l}\text { Is BCVA evaluable? } \\
\text { n (\%) }\end{array}$ & $\begin{array}{l}20 \\
(83.3)\end{array}$ & $40(56.3)$ & $1(50)$ & 0.057 & $\begin{array}{l}10 \\
(100)\end{array}$ & $14(46.7)$ & 0.003 \\
\hline BCVA Ptosis & $\begin{array}{l}0.1[0 \\
-0.4]\end{array}$ & $0.1[0-0.3]$ & $1[1-1]$ & 0.263 & $\begin{array}{l}0.6 \\
{[0.6-} \\
0.7]\end{array}$ & $\begin{array}{l}0.1[0.0- \\
0.3]\end{array}$ & 0.125 \\
\hline
\end{tabular}

AM: Male; F: Female; MRD: Margin Reflex Distance; BCVA: Best Corrected Visual Acuity; IQR: interquartile range 
* Others: congenital cranial dysinnervation disorders, Genetic, CNS disorders/neurological diseases, Ocular syndromes/orbital diseases. ${ }^{* *}$ Amblyopia was analysed on the subgroup of patients for which information was available. *** Qualitative variables are expressed as absolute and percentage frequency quantitative data as median and interquartile range (IQR). Significant data are in bold, suggestive p-values in italic.

Table 5. Association between disease categories and general and clinical characteristics in the study cohort, according to patients' subgroups $(\mathrm{n}=137)$. 


\begin{tabular}{|c|c|c|c|c|c|c|}
\hline & \multicolumn{3}{|c|}{ MONOCULAR } & \multicolumn{3}{|l|}{ BINOCULAR } \\
\hline & $\begin{array}{l}\text { Other } \\
(n=74)\end{array}$ & $\begin{array}{l}\text { Isolated } \\
(n=24)\end{array}$ & $\mathbf{p}$ & $\begin{array}{l}\text { Isolated } \\
(n=4)\end{array}$ & $\begin{array}{l}\text { Others } \\
(n=36)\end{array}$ & p \\
\hline Age (yrs.) & $\begin{array}{l}12[7.8- \\
16]\end{array}$ & $12[7-15]$ & 0.683 & $10[6-13]$ & $14[8-16]$ & 0.319 \\
\hline Sex & & & 0.524 & & & 1.000 \\
\hline M & $33(44.6)$ & $12(52.2)$ & & $2(50.0)$ & $18(50.0)$ & \\
\hline$F$ & $41(55.4)$ & $11(47.8)$ & & $2(50.0)$ & $18(50.0)$ & \\
\hline $\begin{array}{l}\text { Polymalphormative syndromes } \\
\text { associated }\end{array}$ & $28(37.8)$ & $3(13)$ & 0.026 & - & $8(22.2)$ & 0.566 \\
\hline Strabismus type & & & 0.353 & & & 0.433 \\
\hline Esotropia & $31(41.9)$ & $6(26.1)$ & & $2(50.0)$ & $12(33.3)$ & \\
\hline Exotropia & $20(27)$ & $9(39.1)$ & & - & $14(38.9)$ & \\
\hline Vertical squint & $23(31.1)$ & $8(34.8)$ & & $2(50.0)$ & $10(27.8)$ & \\
\hline $\begin{array}{l}\text { Strabismus angle deviation } \\
\text { distance }\end{array}$ & $\begin{array}{l}13[4- \\
26.3]\end{array}$ & $14[6-20]$ & 0.812 & $17[4-30]$ & 20 [10-30] & 0.467 \\
\hline Strabismus angle deviation near & $\begin{array}{l}12[4- \\
25]\end{array}$ & $16[8-25]$ & 0.278 & $20[4-35]$ & $21[10-30]$ & 0.585 \\
\hline Vertical strabismus & $0[0-5]$ & $0[0-12]$ & 0.417 & $0[0-0]$ & $0[0-5]$ & 0.236 \\
\hline Strabismus onset, mean (SD) & $2[1-17]$ & $2[1-13]$ & 0.919 & $6[6-6]$ & $1[1-6]$ & 0.108 \\
\hline Strabismus familiar history & $1(1.4)$ & $2(8.7)$ & 0.277 & $2(50.0)$ & $2(5.6)$ & 0.043 \\
\hline Strabismus deviation type & & & 0.066 & & & 0.297 \\
\hline Comitant & $32(43.2)$ & $15(65.2)$ & & $4(100)$ & $24(66.7)$ & \\
\hline Incomitant & $42(56.8)$ & $8(34.8)$ & & - & $12(33.3)$ & \\
\hline Ptosis familiar history & $4(5.4)$ & - & 0.590 & - & $8(22.2)$ & 0.566 \\
\hline Ptosis features & & & 0.275 & & & 1.000 \\
\hline Bilateral-ptosis & - & - & & $4(100)$ & $30(83.3)$ & \\
\hline Bilateral eyelid asymmetry & - & - & & - & $6(16.7)$ & \\
\hline Unilateral ptosis & $49(66.2)$ & $18(78.3)$ & & - & - & \\
\hline Unilateral eyelid asymmetry & $25(33.8)$ & $5(21.7)$ & & - & - & \\
\hline Ptosis MRD (mm) & $3[2-4]$ & $3[2-4]$ & 0.968 & $\begin{array}{l}3.0[2.5- \\
3.5]\end{array}$ & $1.0[1.0-3.0]$ & 0.064 \\
\hline Ptosis onset & $2[1-9.9]$ & $2[1-6]$ & 0.405 & $6[6-6]$ & $1[1-6]$ & 0.108 \\
\hline Levator function & $\begin{array}{l}18[14- \\
18]^{[14}\end{array}$ & $\begin{array}{l}16[15- \\
18]^{[15}\end{array}$ & 0.608 & $\begin{array}{l}15[14- \\
15]\end{array}$ & $8[4-16]$ & 0.221 \\
\hline Refractive error & & & 0.658 & & & 0.556 \\
\hline
\end{tabular}




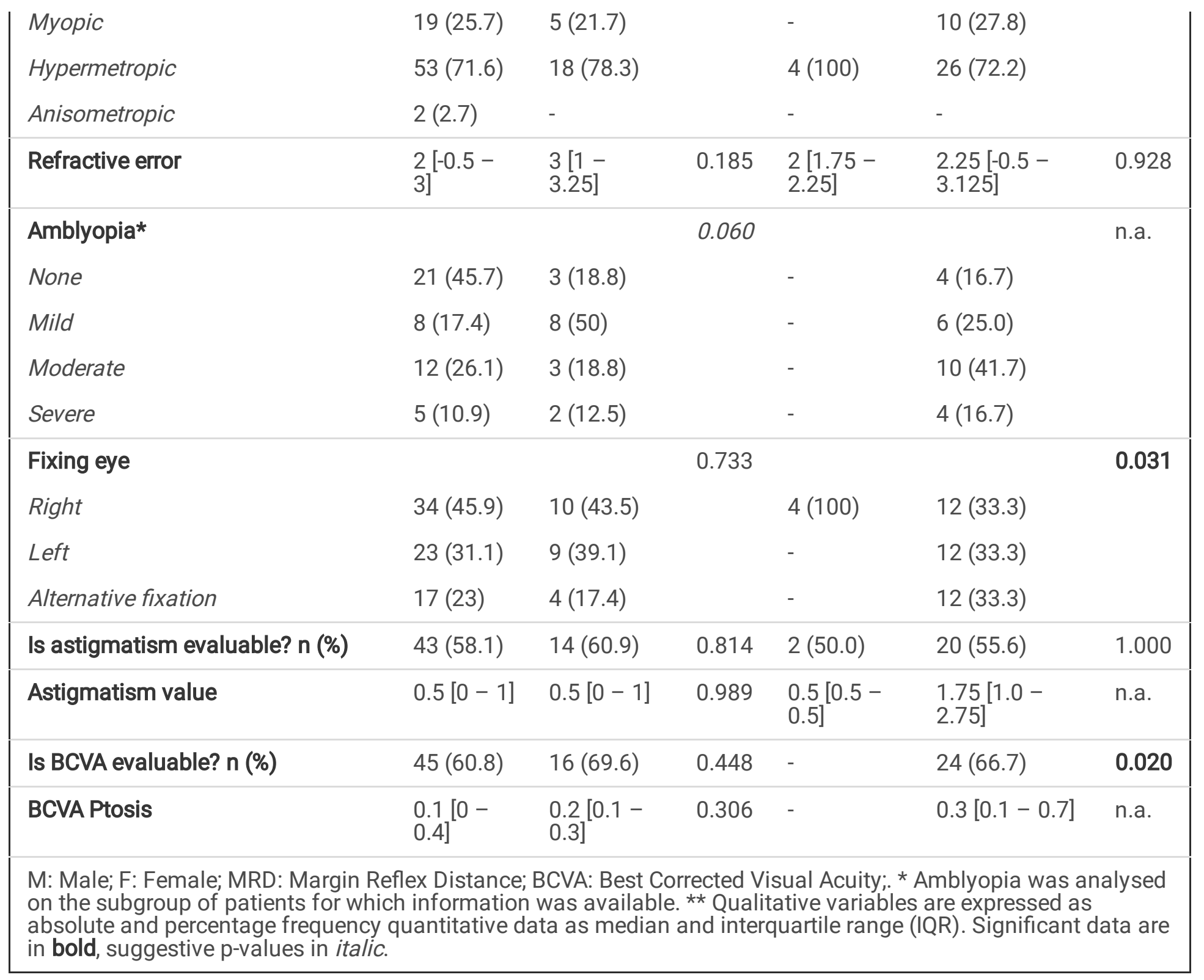

Table 6. Association between amblyopia and general and clinical characteristics in the study cohort according to patients' subgroups. ${ }^{* *}, * \star *$ 


\begin{tabular}{|c|c|c|c|c|}
\hline \multirow[b]{2}{*}{ MONOCULAR DISEASE } & \multicolumn{4}{|l|}{ Amblyopia } \\
\hline & $\begin{array}{l}\text { Absent } \\
(n=24)\end{array}$ & $\begin{array}{l}\text { Mild } \\
(n=16)\end{array}$ & $\begin{array}{l}\text { Moderate } \\
(n=15)\end{array}$ & $\begin{array}{l}\text { Severe } \\
(n=7)\end{array}$ \\
\hline Age (yrs.) & $12[8.5-16]$ & $\begin{array}{l}12.5[8.3- \\
18]\end{array}$ & $11[8-14]$ & $12[12-15]$ \\
\hline \multicolumn{5}{|l|}{ Sex } \\
\hline$M$ & $8(33.3)$ & $6(37.5)$ & $8(53.3)$ & $1(28.6)$ \\
\hline$F$ & $16(66.7)$ & $10(62.5)$ & $7(46.7)$ & $5(71.4)$ \\
\hline \multicolumn{5}{|l|}{ Categories } \\
\hline Isolated & $6(25)$ & $5(31.3)$ & $4(26.7)$ & - \\
\hline Others* & $18(75)$ & $11(68.7)$ & $11(73.3)$ & $7(100)$ \\
\hline Polymalphormative syndromes & - & $4(25)$ & $5(33.3)$ & $3(42.9)$ \\
\hline \multicolumn{5}{|l|}{ Strabismus type } \\
\hline Esotropia & $6(25)$ & $7(43.8)$ & $5(33.3)$ & $1(14.3)$ \\
\hline Exotropia & $6(25)$ & $4(25)$ & $6(40)$ & $3(42.9)$ \\
\hline Vertical squint & $12(50)$ & $5(31.3)$ & $4(26.7)$ & $3(42.9)$ \\
\hline Strabismus angle deviation distance & $12[0-17.5]$ & $16[8-20]$ & $15[4-35]$ & $20[6-30]$ \\
\hline Strabismus angle deviation near & $8[4-15.5]$ & $14[7-23.3]$ & $20[8-35]$ & $12[6-25]$ \\
\hline Vertical strabismus & $1[0-8]$ & $0[0-9]$ & $0[0-0]$ & $0[0-5]$ \\
\hline Strabismus onset & $4.5[1-48]$ & $4[1-110.9]$ & $4[1-30]$ & $6[1-21.5]$ \\
\hline Strabismus familiar history & $3(12.5)$ & - & - & - \\
\hline \multicolumn{5}{|l|}{ Strabismus deviation type } \\
\hline Comitant & $9(37.5)$ & $8(50)$ & $9(60)$ & $4(57.1)$ \\
\hline Incomitant & $15(62.5)$ & $8(50)$ & $6(40)$ & $3(42.9)$ \\
\hline \multicolumn{5}{|l|}{ Ptosis features } \\
\hline Bilateral ptosis & - & - & - & - \\
\hline Bilateral eyelid asymmetry & - & - & - & - \\
\hline Unilateral ptosis & $16(66.7)$ & $10(62.5)$ & $11(73.3)$ & $6(85.7)$ \\
\hline Unilateral eyelid asymmetry & $8(33.3)$ & $6(37.5)$ & $4(26.7)$ & $1(14.3)$ \\
\hline Ptosis familiar history & - & - & $1(6.7)$ & $1(14.3)$ \\
\hline Ptosis MRD (mm) * & $3[3-4]$ & $3.5[2.3-4]$ & $3[2-4]$ & $2[1-4]$ \\
\hline Ptosis onset & $3.5[1-57]$ & $2[1-6]$ & $4[2-6]$ & $6[1-21.5]$ \\
\hline Levator function & $\begin{array}{l}18[16.3- \\
18.8]\end{array}$ & $18[16-18]$ & $16[14-18]$ & $16[10-18]$ \\
\hline
\end{tabular}




\section{Refractive error}

Myopic

9 (37.5)

4 (25)

4 (26.7)

3 (42.9)

Hypermetropic

15 (62.5)

$12(75)$

11 (73.3)

3 (42.9)

Anisometropic

\begin{tabular}{|c|c|}
\hline $1.4[-0.5-2.9]$ & $\begin{array}{l}2.8[-0.1- \\
3.4]\end{array}$ \\
\hline
\end{tabular}

1 (14.2)

Refractive error

\section{4]}

\section{Fixing eye}

Right

11 (45.8)

5 (31.3)

11 (73.3)

4 (57.1)

Left

8 (33.3)

8 (50)

1 (6.7)

$3(42.9)$

Alternative fixation

5 (20.8)

3 (18.8)

3 (20)

Is astigmatism evaluable?

15 (62.5)

10 (62.5)

$9(60)$

5 (71.4)

Astigmatism value

$0.5[0-1]$

$0.63[0-1]$

$0.5[0-1.25]$

$1[0-1]$

Is BCVA evaluable?

23 (95.8)

16 (100)

15 (100)

7 (100)

BCVA Ptosis

0 [0 - 0]

$0.1[0.1-$

$0.2]$

BINOCULAR DISEASE

Absent

Mild

$0.4[0.3-0.5]$

$1[1-1]$

Age (yrs.)

$(\mathrm{n}=4)$

$(n=6)$

Moderate

Severe

\section{Sex}

M

$$
13[10-16]
$$

$13[12-16]$

$(n=10)$

$(n=4)$

F

$$
2 \text { (50) }
$$

4 (66.7)

$6(60)$

2 (50)

2 (33.3)

4 (40)

4 (100)

\section{Categories}

Isolated

Others*

$4(100)$

6 (100)

$10(100)$

$4(100)$

\section{Polymalphormative syndromes}

association

\section{Strabismus type}

Esotropia

2 (50)

2 (100)

Exotropia

$2(50)$

2 (33.3)

$6(60)$

Vertical squint

$0 \quad 4(66.7)$

$4(40)$

Strabismus angle deviation distance

Strabismus angle deviation near

$8[6-10]$

30 [10 - 35]

$9[8-10]$

40 [10 - 55]

$0[0-0]$

5 [0 - 50]

55 [1 - 108]

$1[1-6]$

$6[6-6]$

25 [25 - 30]

$4(100)$

Strabismus onset

Strabismus familiar history 


\begin{tabular}{|c|c|c|c|c|}
\hline \multicolumn{5}{|l|}{ Strabismus deviation type } \\
\hline Comitant & $4(100)$ & $4(66.7)$ & $6(60)$ & - \\
\hline Incomitant & - & $2(33.3)$ & $4(40)$ & $4(100)$ \\
\hline \multicolumn{5}{|l|}{ Ptosis features } \\
\hline Bilateral ptosis & - & $6(100)$ & $10(100)$ & $4(100)$ \\
\hline Bilateral eyelid asymmetry & $4(100)$ & - & - & - \\
\hline Unilateral ptosis & - & - & - & - \\
\hline Unilateral eyelid asymmetry & - & - & - & - \\
\hline Ptosis familiar history & - & - & $6(60)$ & - \\
\hline Ptosis MRD (mm) * & $4.0[3.5-4.5]$ & $\begin{array}{l}1.0[1.0- \\
3.0]\end{array}$ & $1.0[0.0-1.0]$ & $\begin{array}{l}1.0[0.5- \\
1.5]\end{array}$ \\
\hline Ptosis onset & $55[1-108]$ & $1[1-6]$ & $6[6-6]$ & $69[1-138]$ \\
\hline Levator function & $17[16-18]$ & $14[5-18]$ & $3[3-4]$ & $6[2-9]$ \\
\hline \multicolumn{5}{|l|}{ Refractive error } \\
\hline Myopic & - & - & $8(80)$ & $2(50)$ \\
\hline Hypermetropic & $4(100)$ & $6(100)$ & $2(20)$ & $2(50)$ \\
\hline Anisometropic & - & - & - & - \\
\hline Refractive error & $2.4[2.3-2.6]$ & $\begin{array}{l}1.0[0.0- \\
1.5]\end{array}$ & $-3.0[-4.0--2.0]$ & $\begin{array}{l}1.0[-0.5- \\
2.5]\end{array}$ \\
\hline \multicolumn{5}{|l|}{ Fixing eye } \\
\hline Right & $2(50)$ & $2(33.3)$ & $4(40)$ & $2(50)$ \\
\hline Left & $2(50)$ & - & $2(20)$ & $2(50)$ \\
\hline Alternative fixation & - & $4(66.7)$ & $4(40)$ & - \\
\hline Is astigmatism evaluable? & $2(50)$ & $2(33.3)$ & $8(80)$ & $2(50)$ \\
\hline Astigmatism value & $\begin{array}{l}0.75[0.5- \\
1.0]\end{array}$ & $\begin{array}{l}2.5[2.5- \\
2.5]\end{array}$ & $\begin{array}{l}2.50[1.75- \\
3.00]\end{array}$ & $\begin{array}{l}2.0[1.0- \\
3.0]\end{array}$ \\
\hline Is BCVA evaluable? & $4(100)$ & $6(100)$ & $10(100)$ & $4(100)$ \\
\hline BCVA Ptosis & $0[0-0]$ & $\begin{array}{l}0.1[0.1- \\
0.1]\end{array}$ & $0.6[0.3-0.6]$ & $0.95[0.85-1]$ \\
\hline \multicolumn{5}{|c|}{ M: Male; F: Female; MRD: Margin Reflex Distance; BCVA: Best Corrected Visual Acuity; } \\
\hline $\begin{array}{l}\text { * Others: congenital cranial d } \\
\text { syndromes/orbital diseases. } \\
\text { available. *** Qualitative vari } \\
\text { median and interquartile rang }\end{array}$ & $\begin{array}{l}\text { sorders Genetic } \\
\text { as analysed on } \\
\text { sed as absolute }\end{array}$ & $\begin{array}{l}\text { NS disorders, } \\
\text { subgroup o } \\
\text { id percentag }\end{array}$ & $\begin{array}{l}\text { urological disease } \\
\text { tients for which in } \\
\text { equency quantitat }\end{array}$ & $\begin{array}{l}\text { cular } \\
\text { rmation was } \\
\text { data as }\end{array}$ \\
\hline
\end{tabular}

